\title{
THE RELATIONS BETWEEN CATALONIA AND THE EUROPEAN UNION AND CATALAN INDEPENDENCE REFERENDUM
}

\section{Selcen ÖNER*}

\section{Abstract}

This article analyses the relations between Catalonia and the European Union, while focusing on Catalan independence referendum on October 1, 2017, its historical background and the EU's policy in this process. Semistructured, face to face in-depth expert interviews were conducted by the author in Barcelona in June 2017 before the referendum. Firstly the historical background of Catalan nationalism and relations between Catalonia and the central government in Spain are evaluated. Secondly, relations between Catalonia and the EU and how it has influenced Catalonia-central government relations are analysed. Lastly, the reasons of the Catalan referendum and the policy of the EU are evaluated.

Keywords: Catalonia, Spain, European Union, 'Europe of Regions', Independence Referendum.

\section{KATALONYA VE AVRUPA BİRLİĞİ ARASINDAKİ İLIŞKILER VE KATALAN BAĞIMSIZLIK REFERANDUMU}

\section{$\ddot{O} z$}

Bu makalede Katalonya ve Avrupa Birliği (AB) arasındaki ilişkiler, özellikle 1 Ekim 2017'de yapılan Katalonya bağımsızlık referandumu, tarihi arka planı ve bu süreçte AB'nin izlediği politikalara odaklanilarak incelenmektedir. Referandum öncesinde Barselona'da Haziran 2017'de ilgili uzmanlarla yüz yüze yarı yapılandırılmış derinlemesine mülakatlar yapılmıştır. Illk olarak Katalan milliyetçiliğinin tarihi arka planı ve Katalonya ile İspanya merkezi hükümeti arasındaki ilişkiler değerlendirilmektedir. İkinci olarak, Katalonya ile

\footnotetext{
* Assoc. Prof. Dr., Bahçeşehir University, Faculty of Economics Administrative and Social Sciences, Department of Political Science and International Relations, e-mail:
} selcen.oner@eas.bau.edu.tr. 
$A B$ arasındaki ilişkiler ve bunun Katalonya ile merkezi hükümet arasındaki ilişkilere etkisi analiz edilmektedir. Son olarak da Katalonya referandumunun nedenleri ve AB'nin izlediği politika incelenmektedir.

Anahtar Kelimeler: Katalonya, İspanya, Avrupa Birliği, 'Bölgeler Avrupası', Băğmsızlık Referandumu.

\section{Introduction}

Spanish history has been usually analyzed in terms of a permanent struggle between the centre and the periphery. Its political system may be defined as a 'quasi-federal system'. From the $15^{\text {th }}$ to $17^{\text {th }}$ centuries, the centre played a leading role. However, this equilibrium was lost from the moment Castile began to experience a downturn in its economic power. Although the economic initiative passed to the regions, political power stayed in Madrid, which increased tensions between centre and periphery (Teich and Porter, 1993:106121).

Nationalist movements emerged in Catalonia, the Basque Country and Galicia in the late $19^{\text {th }}$ and early $20^{\text {th }}$ centuries, demanding regional selfgovernment and the restoration of their traditional languages and laws.

During the Franco era, the central government tried to eliminate Spain's territorial, political, and cultural heterogeneity (Keating, 1988: 144-145). After the death of Franco in 1975, Juan Carlos became the king of Spain and the head of the state. During the transformation towards democracy in Spain, he played an important role as a symbol of unity (Conversi, 2000: 159).

After elections in 1977, Spain applied for membership to the European Community (EC). After the introduction of the new constitution in 1978, historical regions gained autonomy: Catalonia and the Basque Autonomous Community (BAC) in December 1979, Galicia in April 1981, followed by other regions later.

Spain is divided into 17 autonomous communities, each with its own executive, parliament and court of justice (Coates, 1998: 259-271). The second article of the constitution states that:

The Spanish Constitution is based on the indissoluble unity of the Spanish nation, common and indivisible motherland of all Spaniards, recognizes and guarantees the right to autonomy of all the nationalities and regions which comprise it and the solidarity among them all.

Catalonia is more prosperous than Spain in general, at around 20\% above the national average; it is also above the European average. In 2016, Catalonia 
was the source of $25.6 \%$ of total Spanish exports and the destination of $20.7 \%$ of foreign direct investment (Elcano Royal Institute, 2018: 7).

Although the role of regions has increased in Europe since the late 1980s, which has enabled them to gain greater access to EU institutions, they are still controlled by member states (Nagel, 2004: 59). Europe's sub-national regions have tried to use the EU to exert indirect influence on nation-states to increase their autonomy. They have been trying to create direct links with the EU by establishing offices in Brussels, through the Committee of the Regions (COR) or by establishing cooperative organizations among themselves. According to the 'sandwich thesis', the state is caught between and must share its powers with the levels above and below (Eser, 1991; cited in Nagel, 2004: 59). With the increase in importance of sub-national regions, the idea of a 'Europe of Regions' started to be discussed in Europe, especially after the 1990s.

EU is usually perceived as an instrument to defend the European nationstate against pressures from above and below (Nagel, 2004: 129). On the other hand, there have been increasing demands for independence from historical regions such as Catalonia. Especially since the latest economic and migration crises, there has been rise in populism, radical right, and Euroscepticism throughout Europe, while the Brexit referendum result has challenged the EU project. These circumstances have increased the importance and influence of nation-states, with growing demands for stricter border controls, and stricter immigration and refugee policies in many states.

This article analyzes the historical background of the relations between Catalonia and the EU, in addition to this, the reasons behind Catalan independence referendum of 1 October 2017 and the EU's policy during this process. The fieldwork was done in June 2017 in Barcelona. The author conducted semi-structured face to face in-depth expert interviews with several academics who are specialised on Catalan issue and European politics, a representative from a civil society organisation and one former Catalan politician. In addition to these interviews, the statements and discourse of the political elites of the EU on Catalan issue are analysed as well.

This article firstly analyzes the historical background of Catalan nationalism, the autonomy process of Catalonia and relations between Catalonia and Spain's central government. The second part discusses relations between Catalonia and the EU and how it has influenced relations between Catalonia and the central government. Lastly, it evaluates the Catalan independence referendum in 2017, its historical background, the reasons behind it, and the policy of the EU about Catalan referendum and the discourse of the EU political elites. 


\section{The Historical Background of Catalonia}

The origins of Catalan identity can be traced back to the Middle Ages, when it emerged as a defined territory with its own language and culture (Keating, 1996: 115). Between the $15^{\text {th }}$ and the middle of the $17^{\text {th }}$ century, Catalonia was under the control of Aragon and Spain (Gibbons, 1999: 273-274). The Spanish monarchy tried to reduce Catalonia's autonomy from the $17^{\text {th }}$ century to establish a centralized state. In 1716, the decrees of Nueva Planta suppressed Catalonia's special constitutional arrangements, which has included Generalitat, ${ }^{l}$ legal competencies and a tax regime. The decrees also made Castilian (Spanish) the language of administration and justice (Keating, 1996: $116)$. Before the $19^{\text {th }}$ century saw a period of prosperity that coincided with a cultural revival that led to demands for political autonomy (Gibbons, 1999: 274).

Catalanism took an explicitly political form from the late $19^{\text {th }}$ century under the leadership of the bourgeoisie. Catalonia had industrialized and modernized earlier than most other parts of Spain except for the Basque region, and had become influential at a European level as well (Gispert and Prats, 1978; cited by Keating, 1996: 117-118).

The first nationalist program was formulated by federalist Valenti Almirall (1841-1904). He emphasised language (Conversi, 1990: 5). Catalan nationalism mainly emerged from the crisis of 1898, when the loss of Spanish colonies caused a loss of important markets. In this era, a group of people from the Catalan bourgeoisie firstly created the 'Union Regionalista' and later established the political party 'Liga Regionalista' in 1901, together with a group of young professionals and intellectuals that dominated Catalan politics until the $2^{\text {nd }}$ Republic (1931-1936) (Diaz Lopez, 1982: 126).

The most important achievement in the early $20^{\text {th }}$ century was establishing the Mancomunitat (1914-23), which was a weak form of self-government that gave administrative autonomy to four Catalan provinces. Despite its limited powers, it provided Catalans with a platform to express their thoughts, helped revive their language and established Catalan economic and cultural institutions (Keating, 1996: 119). However, Primo de Rivera's dictatorship shut it down.

The Catalan Republic was proclaimed on 14 April 1931 within a nonexistent Spanish Federal Republic. The Generalitat was restored ${ }^{2}$ and its statute of autonomy was approved in September 1932 (Moxon-Browne, 1989: 48;

\footnotetext{
${ }^{1}$ The Generalitatis the official name of the group of autonomous political institutions made up of the Parliament, the President of the Generalitat, the Executive Council, the High Court and the Ombudsman.

${ }^{2}$ It had been firstly founded in 1289 .
} 
cited by Gibbons, 1999: 274). The Spanish Parliament accepted the Catalan Statute, through which the Generalitat assumed important autonomous powers, except in international relations. However, the transfer of these powers was delayed because of reluctance of Spain's central administration (Diaz Lopez, 1982: 129). The Parliament of Catalonia was established on 6 December 1932 with Lluis Companys as its first President. However, Catalans lost their shortlived autonomy during the $2^{\text {nd }}$ Republican era (1931-6), and their statute of autonomy was abolished after they sided with the Republic in the Spanish Civil War (1936-39) (Moxon-Browne, 1989 : 48; cited by Gibbons, 1999: 274).

In 1939, the institutions of the Generalitat passed into exile, and its leaders were either executed or went into exile. During Franco era, self-governing Catalan institutions were suppressed, and only Spanish could be used in the administration, courts and education, while even speaking Catalan in public was forbidden for a time. From the 1960s, the regime adopted more liberal economic policies that improved industrialization in Catalonia while there was a cultural revival as well (Keating, 1996: 120-121).

Catalonia was among the first regions to gain autonomy in the post-Franco era. A new Statute of Autonomy was approved in 1979, and the first election to the parliament of Catalonia was held in 1980 (The New York Times, 2017). Tarradellas, the president of the Catalan government, returned from exile in France while the leader of Convergence and Union (CiU), Jordi Pujol, became the Catalan parliament's first president after the first democratic election in the post-Franco era (Guibernau, 2000).

The main goals of the governments formed by the nationalist CiU coalition were a language policy that favoured Catalan in public administration, public media and education, and building a Catalan cultural nation (Colomer, 2017: 951). Language remains the crucial marker of Catalan identity (Nagel, 2004: 64).

Catalonia's degree of autonomy was revised in the 2006 Catalan Statute. However, Spain's Constitutional Court ruled in 2010 that certain articles were unconstitutional. Catalonia has extensive powers in civil law, police, culture, language, education, healthcare, agriculture, industry and trade. Although foreign policy is still an exclusive power of Spain's central government, the regional government has its own external action service and a network of offices abroad (Elcano Royal Institute, 2018: 10).

Catalonia has had two main mainstream parties: the centre-left Catalan branch of the Spanish Socialist Party - the Party of the Socialists of Catalonia (PSOE-PSC), and centre-right regionalist CiU, which held office for most of the period between 1980 and 2010 (Molina, 2015). 
In recent years, the $\mathrm{CiU}$ has moved from a moderate position to demanding Catalan independence. It wanted to reform the Catalan Statute of Autonomy with a demand for fiscal sovereignty and, by 2012, a commitment to creating Catalonia's own state. These efforts increased internal divisions about the CiU's ultimate goal and how it should achieve it, which led to the CiU's breakup in 2015. The Democratic Convergence of Catalonia (CDC) has committed itself to pushing for separating Catalonia from Spain whereas the Democratic Union of Catalonia (UDC) has defended the goal of full sovereignty through negotiation and compromise with the Spanish state (Elias and Mees, 2017: 131-143).

Allegations of corruption in public office, internal tensions about Pujol's successor as party leader and unpopular legislative alliances with the Popular Party (PP) in Spanish and Catalan parliaments during the late 1990s and early 2000s were influential in transforming the CiU's goals. An organizational renewal process led by the CDC brought several pro-sovereignty activists into the party, who were dissatisfied with the CiU's strategy of advancing Catalan autonomy gradually through bilateral negotiations with the central government. This approach became more influential in CDC from 2010 onwards, after the Constitutional Court annulled large parts of the revised Catalan Autonomy Statute, which had been approved by referendum in 2006. This decision led to mass mobilisation in favour of Catalan independence (Elias and Mees, 2017: 147-148).

Especially after the 2008 economic crisis, the CiU demanded fiscal sovereignty for Catalonia. However, the PP blocked attempts to negotiate an increase in fiscal competencies and the CiU's efforts to hold a referendum on Catalan independence. Such opposition increased support for Catalan independence 48.9\% in 2014 (Centre d'Estudis d'Opinio; cited in Elias and Mees, 2017: 149). The CDC and UDC adopted very different strategies in the 2015 Catalan elections. The former was part of a new pro-independence alliance $(\mathrm{JpS})$, which presented the elections as a de-facto referendum on Catalonia's future, whereas the latter followed the CiU's historical commitment to negotiation. Despite the corruption investigations involving CDC and its leader Pujol, JpS emerged as the largest party with $39.6 \%$ of the vote, which gave it a majority in the Catalan parliament with other pro-independence parties (Elias and Mees, 2017: 149).

Recent Catalan governments have declared that their goal is to build state structures in those fields that are not yet part of Catalonia's autonomous competencies, such as taxation, justice and international relations, and to hold a referendum to declare independence unilaterally (Colomer, 2017: 952). All these developments led to the independence referendum of 2017. Thus, the rising tensions between Madrid and Barcelona and the economic crisis have had 
crucial role in the rise of influence of the independence demands in Catalonia and transformation of its main goal from increasing its autonomy to independence from Spain, however maintaining its place inside the EU.

\section{The Relations between Catalonia and the EU}

In some regions of EU member states, especially those that can be defined as stateless nations; there are powerful autonomist or separatist movements that mostly see the EU as a way to by-pass the nation-state (Keating, 1995: 21). However, regarding finance, the EU remains a state-centric polity in that any regional government needs to operate through national rather than European channels to access EU funds (Nagel, 2004: 130).

The Catalan lobby in Brussels, the Patronat Catala Pro Europa, was founded in 1982. It is a public-private body that lobbies for Catalan interests. It was primarily established to monitor developments in the EU, and it shares information with Spain's permanent representation, working in cooperation with the Spanish government (Keating, 1996: 157). The foundation of a Catalan lobby in Brussels even before Spain's EC membership shows Catalonia's level of interest in the EU from the beginning.

On 1 January 1986 Spain became a member of the EC. Europeanization has posed challenges to Spain's territorial system. Firstly, regarding the centralization of regional competencies, the Spanish Constitution allows both national and regional competencies to be transferred to the EU without requiring the approval of the autonomous communities, which has caused them to lose many competencies in agriculture, fisheries, industry, economic planning, environment and social welfare. The efforts of Spain's central government to improve the implementation of European policies have thus increased the centralization of regional competencies (Börzel, 2000: 22-24).

A Constitutional Court ruling permitted the autonomous regions to establish their own consulates, for example in Brussels, where they have the right to negotiate directly with EU officials (Gibbons, 1999: 284). However, there is no general mechanism to involve the autonomous communities in determining Spain's national policy on European matters (Keating and Hooghe, 1996: 221). During Spain's first presidency of the EU in 1989, 12 of the 17 autonomous communities opened offices in Brussels (Coates, 1998: 264).

Following an EP resolution in 1990, Catalan was recognized as a European language. It was hoped that this would lead to Catalan being recognized as one of the EU's official languages for debate and simultaneous translation in the EU. However, the EP did not grant this recognition (Keating, 1996: 158). 
On the other hand, Catalonia has been very active in interregional networking in Europe. In 1991, it signed an agreement to create a Euro-region alongside the French regions of Midi-Pyrenees and Languedoc-Roussillon (Keating, 1996: 157). In addition, Catalonia is a member of a Pyreneen working group and the 'four motors of Europe' (Gibbons, 1999: 283).

The representation of Spain's autonomous communities at the COR gives them greater influence over the EU decision-making. However, the Spanish government opposed the COR proposals that would have given these regions the same level of policy influence that Belgian and German regions already have in the cultural affairs council meetings through their official status as participants (Gibbons, 1999: 284).

The stateless nationalists may respond to European integration in three main ways. Firstly, they may fight against the EU. Secondly, they may use the channels offered by the EU to play the game according to the established rules. Thirdly, they may seek independence within the EU by demanding recognition as just another member state. Catalonia is a very active player at the European level. Catalan nationalists initially chose the second way, however, especially after 2010; they have chosen the third way. Catalan nationalists have always emphasized their Europeanness (Nagel, 2004: 58-65) while searching for opportunities in Europe to improve their political, economic and cultural interests (Keating, 1996: 225).

The CiU sees Europe as an outlet for their nationalist aspirations, a political arena that may help to develop their autonomy, and a stage on which they can show themselves internationally (Keating, 1996: 129). Pujol thinks that the regions and the EU have a common interest, which is weakening the nation-state. He emphasizes Catalonia's Europeanness and thinks that the most important future actors in Europe will be the regions and the EU itself (Newhouse, 1997: 69). The CiU program demanded the participation of the Generalitat in the Council of Ministers. It also supports strengthening the COR's powers and general improvements in links between Catalonia and European institutions. It also emphasized the importance of developing the principle of 'subsidiarity' to retain those competencies that are transferred to the Generalitat by the central government and to block their transfer to Brussels. The CiU also promoted Catalan and demanded its recognition as an official EU language (Gibbons, 1999: 286).

Catalonia plays a prominent role in improving the position of sub-national regions in the EU decision-making (Keating, 1996: 162). However, this is still limited because national governments still play the most prominent role in the EU. Despite its popularity in the 1990s, the idea of a 'Europe of regions' has significantly decrease its influence, especially in recent years. 


\section{The Catalan Independence Referendum of 2017 and its Historical Background}

In recent years, on the one hand, there have been centralization attempts in Spain while, on the other hand, there have been demands and mobilizations for independence of Catalonia although they want to remain as a separate EU member. Since the beginning of the $21^{\text {st }}$ century tensions have risen in relations between Catalonia and the Spanish state (Colomer, 2017: 950-953).

When Aznar, came to power in Spain as the PP leader, he tried to stop decentralization. The ERC (Republican Left of Catalonia), led by CarodRovira, offered to form a coalition with the $\mathrm{CiU}$ in the Catalan government to polarize Catalan nationalists against the PP. However, Pujol rejected this proposal because he expected to enter negotiations with the Spanish government. A three-party coalition government formed by the PSC, the ERC and the Initiative for Catalonia Greens (ICV), chaired by Pasqual Maragall, was established in 2003. The new government was Catalanist and leftist. The Pact of Tinell signed by the new Catalan government excluded any governmental or parliamentary agreement with the PP. The government's first goal was to introduce a new Statute of Autonomy of Catalonia, which was approved by the Catalan parliament and renegotiated with the Spanish government. After revision by the Spanish parliament, it was ratified by a referendum in Catalonia. However, the ERC, which had been the main promoter of this statute, voted against it and started to make new demands, such as the recognition of Catalonia as a nation, fiscal decentralization and control of large infrastructure by the Catalan parliament. In response, the PP started a campaign in Spain to collect a few million signatures to call for a Spain-wide referendum against the Catalan statute and to defend a 'single Spanish nation'. It also appealed against the statute at the Constitutional Court (Colomer, 2017: 959-960).

The new Statute of Autonomy was approved in the Catalan Parliament and approved by $48 \%$ of the Catalans in 2006 . However, the Constitutional Court declared several articles unconstitutional in June 2010. One month later a massive demonstration took place in Barcelona under the motto 'we are a nation; we decide'. Twelve Catalan newspapers declared in November 2009 that a more radical solution might emerge because of the central government (Europenow Journal, 2018).

The independence efforts in Catalonia have been mostly an elite-driven, politically-motivated strategy that became prominent due to increasing confrontation with the Spanish government (Colomer, 2017: 950). The central government has also influenced rise of Catalan separatism, especially by trying to re-centralize power (Molina, 2015). Thus, the rising tensions between 
Catalan government and Madrid had triggered the momentum of demands for independence of Catalonia.

After 2009, Catalonia faced its biggest economic crisis since the Civil War. This increased radicalization of several parties, caused high polarization and the collapse of the party system in Catalonia, which damaged the existing autonomy (Colomer, 2017: 950). In 2012, fiscal negotiations broke down between the CiU-led government and the Spanish government led by the PP after the latter rejected calls of the Catalan government for a similar degree of fiscal control as the Basque Country and Navarra (Lawson).

'Catalonia, a new state in Europe' was the motto of the September 2012 demonstration in Barcelona, which marked the beginning of the independence referendum campaign. Although Catalonia wants to remain in the EU, the EU has strict rules for enlargement, as openly expressed by several EU political officials. For example, former Commission President Prodi (2004) stated that:

When a part of the territory of a member state ceases to be a part of the state, because that territory becomes an independent state, the treaties will no longer apply to that territory (cited by Elcano Royal Institute, 2017: 15).

There were massive demonstrations organized by Catalan proindependence organizations like Omnium Cultural in Barcelona during Catalonia's national holidays in 2011 and 2012. During this period Catalan Prime Minister Artur Mas tried to negotiate a better fiscal pact with the central government in September 2012. This idea was rejected by Spanish former Prime Minister Rajoy, after which the traditionally moderate $\mathrm{CiU}$ abandoned cooperation with the central government. Mas called for new elections in November 2012. However, CiU lost power whereas the pro-independence ERC doubled its seats, giving pro-independence parties half of the Catalan Parliament. In January 2013, the parliament approved a sovereignty declaration and the Catalan's right to decide. In 2013 and 2014, following Scotland's example, the Catalan government supported the idea of a referendum for independence. Although it was declared unconstitutional by the Constitutional Court, a non-binding referendum took place in November 2014, with $37 \%$ of Catalans participating, of whom $80 \%$ supported an independent Catalonia. In September 2015, the CiU and ERC joined forces in an election coalition called 'together for yes', winning 39\% of the votes (Europenow Journal, 2018).

The Catalan independence movement has tried to internationalize the issue. The independence movement has tried to convince outside players, especially the EU, to pressure Madrid to accept a referendum (Elcano Royal Institute, 
2017: 23). However, foreign support for Catalan independence has been very limited.

Two NGOs played a crucial role before the independence referendum. One is Omnium Cultural, established in the 1960s to promote Catalan language and culture but recently transformed into a movement demanding selfdetermination. The other one is the Catalan National Assembly (ANC), established to promote creation of a new Catalan state. Its two presidents were former members of the ERC. These organizations organized several street marches and demonstrations, such as the one against the Constitutional Court's decision, another on the National Day of Catalonia in 2012 under the motto 'Catalonia, a new state of Europe', the human chain 'A Catalan way to independence' in 2013, ' $\mathrm{V}$ ' as for voting for independence in 2014 and 'Free way to the Catalan Republic' in 2015 (Colomer, 2017: 962-963).

By 1999, pro-independence parties controlled $16 \%$ of the Catalan Parliament whereas in 2015 they gained 48\% of the seats (Europenow Journal, 2018). Thus, there has been a huge increase in Catalonia in the level of supporters of independence especially since 2010 .

On 1 October 2017, the independence referendum was held in which several stakeholders, including politicians, activists, academics, business people, entrepreneurs and public managers presented themselves as a collective plural leadership (Calzada, 2017: 67-68).

'Catexit' would also mean exit from the EU as well, as made clear by the European Commission and other European high officials. They added that an independent Catalan state would have to apply for EU membership (Colomer, 2017: 960). The possibility of a unilateral declaration of independence is widely rejected by the EU as an attack on the sovereignty of a member state in line with Article 4.2 of the Treaty on the EU. Moreover, the COR also declared that any EU region that gained independence would have to apply to enter the EU (Europenow Journal, 2018).

The European Commission (2017) stated that 'under the Spanish Constitution, the vote in Catalonia was not legal'. For the Commission, as President Juncker stated repeatedly:

This is an internal matter for Spain that has to be dealt with in line with the constitutional order of Spain ... If a referendum were to be organised in line with the Spanish Constitution it would mean that the territory leaving would find itself outside the EU ... We call on all relevant players to now move very swiftly from confrontation to dialogue ... We trust the leadership of Prime Minister Mariano Rajoy to manage this difficult process in full respect of the Spanish Constitution and of the fundamental rights of citizens. 
The independence referendum took place on October 1, 2017. Only 43\% of Catalans participated because the referendum was boycotted by opponents of secessionism, in addition to this, Spanish police tried to prevent the referendum, there was a very harsh reaction and even violence of some policemen against several voters. At the end, independence supporters gained $90.1 \%$ of the votes. The harsh reaction by the central government during the referendum campaign allowed Catalan pro-independence movements to 'portray Spain as an anti-democratic and anti-Catalan country'. Moreover, some Catalan pro-independence leaders were jailed because of riots before the referendum (Europenow Journal, 2018), when hundreds were injured in clashes with the police. According to the Catalan authorities, it was one of the toughest tests of Spain's democracy since the end of the Franco era (The New York Times, 2017). The violent events during the referendum because of the intervention of the National Police and the Civil Guard led to criticism from the EU and other international actors (Elcano Royal Institute, 2018: 26).

After the referendum, 70 of the 135 members of the Catalan government made a unilateral declaration of independence on 27 October 2017. In response, the Spanish government set in motion Article 155 of the Constitution, with the approval of the Senate. This involved suspending selfgovernment and dissolving the Catalan government, with Madrid calling new regional elections on 21 December (Elcano Royal Institute, 2017: 26). Meanwhile, the Constitutional Court ruled the declaration of independence null. On October 30, 2017, Puigdemont fled to Brussels in search of international support. On November 2, 2017, some of his fellow councillors were jailed for organizing the referendum. Meanwhile, the EU maintained its stance that this was Spain's internal affair. Puigdemont then described the EU as 'club of decadent, obsolete countries' and claimed that a referendum was needed for Catalonia to remain in the EU. However, the ERC rejected this idea (Europenow Journal, 2017).

Since the referendum, hundreds of thousands of people have participated in marches in Barcelona, Madrid and other Spanish cities, either in favour of independence or against it (The New York Times, 2017). Despite decreasing tensions between Catalonia and Spain's socialist central government, there are still crucial challenges, of which social polarization within Catalan society is one of the most crucial.

\section{The Analysis of the In-Depth Interviews: Evaluations about the Policy of the EU before the Catalan Referendum}

The author conducted in-depth interviews in June 2017 before the Catalan independence referendum, when it had been still not clear whether the 
referendum could be done or not. The interviewees were academics, experts, a representative from Catalan civil society and a former Catalan politician.

The interviewees all emphasized that the Constitutional Court's decision in 2010 to cancel and reinterpret some articles of the revised Autonomy Statute of Catalonia was a very important turning point that had triggered the proindependence movement in Catalonia. Most of them argued that other solutions had been possible before that. However, hope for a solution ended after that, which led to the rise of the pro-independence movement.

Interviewee 6 (2017) argued that the 1978 Spanish Constitution recognized the existence of a decentralization plan in a dynamic process. Although Catalonia tried to make power sharing between the centre and the regions more asymmetrical, it has developed more symmetrically. It had been thought that 'Spain would become a federal country, not this kind of regionalized country'. The revised statute of autonomy was negotiated in Madrid, downgraded in 2006, approved by the Spanish parliament, sent back to Catalonia and ratified in the 2006 referendum. However, 4 years later, the Constitutional Court decided that some of these articles were unconstitutional. Between 2010-2012, the Catalan government focused on trying to gain more powers, but the statute of autonomy had already been downgraded by Spanish institutions. The first article in the first draft of the statute of autonomy stated that 'Catalan is a nation'. However, this was removed from the text during negotiations in Madrid. The second issue concerned keeping central government out of Catalonia's exclusive powers. For example, Catalonia has exclusive powers regarding culture, yet there is culture law at the Spanish level either. Another expectation from the revision of the statute of autonomy concerned Catalonia's complaints since the beginning of the territorial debate about Madrid's excessive control of fiscal policy, whereby $85 \%$ of taxes are collected by Madrid, followed by regional redistribution. After the Constitutional Court's decision, Catalonia lost hope about reaching a compromise with the central government. Grassroots organizations became increasingly secessionist while internal self-determination was prioritized after 2010. The effects of the economic crisis triggered this process. After the crisis, Catalans declared: 'We do not want Madrid managing our taxes, our money; we have to manage our economy to have the real power'. Interviewee 6 (2017) claimed that although 'the last legal step might be Constitutional reform; the Catalan government had not tried this. Except this legal path, all other legal ways had been explored by Catalan government'.

Interviewee 3 (2017) argued that, 'before 2012 alternative things could be possible, independentism increased after the failure of new statute of autonomy'. He added that: 
The Constitutional Court is not usually perceived as a neutral actor between the centre and the autonomous communities ... The autonomous communities do not have influence in choosing judges of the Constitutional Court.

In 2012, mass mobilizations started for Catalonia's independence. As Interviewee 5 (2017) put it:

The decision of the Constitutional Court really shocked us. The term nation had been deleted; it had been part of the preamble ... It has a symbolic value ... Some articles had been deleted; some had been reinterpreted for the benefit of the central institutions ... There was a backlash ... Most people in Catalonia understood that Spain will never vote for a federal system; there will never be asymmetric treatment for Catalonia ... Then the mood evolved from a defensive stance ... towards a clear proactive stance for independence.

Interviewee 6 (2017) argued that they had tried to organize the previous participatory process as a referendum. Then it had been decided as a participatory process ${ }^{3}$. A delegation of Catalan deputies went to the Spanish parliament to propose an agreement on a referendum. They proposed transfer of powers to Catalonia for that referendum to create a legal and political framework. When these attempts failed, they decided to transform the referendum into a participatory process organized by civil society with no role for civil servants. He added that civil society had been playing a very active role in Catalonia, especially since 2006, the Citizens' Platform was created to promote the right to decide on self-determination. Interviewee 3 (2017) claimed that, before the 2017 referendum, 'the pro-independence supporters could not campaign in Catalonia because it was seen as illegitimate'.

According to Interviewee 5 (2017), after regional elections in September 2015, there was an absolute majority in the Catalan parliament supporting independence. When compared with a non-binding referendum, the Catalan government stated that they would implement this one, immigrants could vote in the previous one, not in the latest one.

According to the interviewees, the PP and former Spanish Prime Minister Rajoy are actors with whom it is hard to reach a compromise. They have had anti-Catalan arguments for a long time. The interviewees argued that PP government used anti-Catalan arguments because they understood that it was effective in electoral terms. On the other hand, as Interviewee 2 (2017) argued, the radical independendists of Catalonia also saw an opportunity from confrontation with the Spanish government. However, he also argues that this was not the dominant opinion of the Catalan population because some were

${ }^{3}$ It is not perceived as binding by Catalan authorities. 
ready to accept a deal if Madrid made some fiscal changes and enabled some sort of federal state. He claimed that, if the Spanish government made some changes to Catalonia's regional autonomy then even pro-independence Catalans could change their position. He argued that the 'Spanish government has an understanding of Spanish nation, Spanish unity which is very traditional and centralist'. Finally, Interviewee 2 (2017) noted that the Catalan issue may damage Spain's reputation of successfully transitioning to democracy. Actually the events and police violence against Catalans who participated in the referendum led to critiques about the successful transition to Spanish democracy.

In contrast, Interviewee 4 (2017), a former Catalan politician, had a different perspective. He argued that:

For pro-independence supporters, independence is just the card to play to get these other things. However, the Spanish government says that if you do not leave this card out, there is nothing to talk about.

Thus, he emphasised that the option of referendum was illegal and not a solution to the Catalan issue.

On the other hand, Interviewee 6 (2017) emphasized that the 'secessionist, independence project in Catalonia has nothing to do with right-wing populisms in Europe'. He added that Catalan's independence movement is not a project of disintegration. Instead, he claimed that:

The pro-independence movement wants independence for integration ... you will not find a single proposal for a Catalan currency, Catalan hard borders, creating a powerful army in Catalonia - that is not the spirit of the project.

He added that 'we experienced fascist dictatorship ... There is a substantial number of immigrants but they were not perceived as threats'. According to Interviewee 2 (2017):

PP is a catch-all party; they try to get the support of radical right voters as well. In addition, immigration has not been such an influential issue in Spain for many years, although immigration has risen in recent years.

While Interviewee 3 (2017) argued that there is a more positive attitude in Catalonia towards immigration and refugees compared to the central government to show that they are more tolerant.

For independentists, immigration is a good issue to demonstrate that they are not ethnic; ... they are also more in favour of accepting more refugees compared to the central government. 
He added that, immigrants had been allowed to vote as well in the previous non-binding referendum; although only the citizens in Catalonia were allowed to vote in the latest referendum.

The interviewees indicated that Spain has become more introverted in recent years, especially after the economic crisis. Interviewee 2 (2017) argued that 'for the Spanish government, the Catalan issue has become the first priority'. He claimed that 'the only strategy they have is to prevent the independence of Catalonia; thus, they are less visible in South America, they are passive inside the EU'. Interviewee 4 (2017) argued that Aznar had tried to change this inward-looking foreign policy. During his term in office, Spain had tried to become a global player again and develop a more proactive foreign policy in Latin America. Under Zapatero, Spain joined Turkey in their 'alliance of civilizations' initiative whereas, during the last period of the Zapatero and Rajoy governments, Spain was not very proactive at EU or global level.

The Basque Country where there had been stronger demands for independence before did not support Catalan independence referendum. Comparing Catalonia's case with the Basque Country, Interviewee 3 (2017) put forward that:

The Basque Country and Navarra could survive the financial crisis much better than all the other autonomous communities that have financial autonomy as well. If Catalonia leaves, then there will be strong Spanish pressure on the Basques to contribute more for the rest of Spain ... Thus, they cannot be in favour of Catalan independence because of their interests.

When it was compared to the Scottish referendum, Interviewee 3 (2017) argued that:

From the perspective of the EU, it is the internal affair of the member states ... The constitution of the UK permits them to go to a referendum for independence, Spanish constitution does not.

The interviewees viewed the EU as a coalition of states, so they do not expect it to move in a federal direction. Regarding the Catalan issue, they do not expect the EU to play a proactive role; rather a neutral one. As Interviewee 2 (2017) noted:

The EU is a coalition of states ... in favour of the status quo ... I do not expect member states to be very active ... they will follow the Spanish state, but they may prevent serious confrontation.

Interviewee 6 (2017) stated that the 'EU is behaving in a way that is expected; the EU is a club of states ... they say this is a Spanish affair, internal affairs'. According to Interviewee 3 (2017), 'official EU policy is that the Catalan issue is the internal affair of Spain ... the EU is not a federation, it is a confederation'. Interviewee 1 (2017) argued that: 
EU states, the Council and European politicians all support Spain's central government. Catalans consider themselves as European ... Spaniards also feel European ... the image of Europe is still positive in Catalonia but there is some kind of disappointment.

In 1990s when there had been higher expectations from the EU in Catalonia to increase its autonomy within Spain further, even which may lead to 'Europe of Regions' changed in recent years. The EU has also focused more on its own problems such as the economic and the migration crises, Brexit, and rise of populist radical right parties.

On the other hand, there were greater expectations by the Commission. Interviewee 2 (2017) claimed that the 'Commission, not in a very open way but in an indirect way ... may try to prevent a major conflict'. Interviewee 5 (2017) stated that:

I would expect the EU institutions to be neutral ... Some authorities within the EU institutional framework have openly supported Rajoy's, Madrid's position ... Their attitude is, this is an internal issue and we will not interfere.

He added that 'I am expecting the Commission at least to mention that Madrid should stop persecuting politicians just for ideas, which is against the core values of the EU'.

Catalans had greater expectations from the COR at the beginning when the idea of independentism was not widespread. As Interviewee 3 (2017) argued, the $\mathrm{CiU}$ had been very confident about the importance of the regions, so there had been an expectation that the influence of member states would decline. However, after the enlargement towards the Central and East European Countries and the economic crisis, the states' influence had increased again.

The idea of a 'Europe of Regions' was particularly popular in Catalonia in the 1990s. Catalonia initiated several forms of cooperation and networks among several regions of Europe in this period. However, as Interviewee 2 (2017) mentioned, 'this idea is not influential now because there are different types of regions and they do not fit well'. Interviewee 6 (2017) stated that:

The big aspiration in Catalonia was 'Europe of the Regions' ... one situation that did not become reality ... the Catalan president created the 'four motors of Europe' with the regions from France, Germany and Italy ... then the Assembly of Regions, COR were created. Catalonia was one of the leading actors in the 1990s that supported the idea of 'Europe of Regions'. This idea was called the 'sandwich thesis': the EU claims more powers from the upper tier of government; the regions undermine the power of the states ... one idea of the 'sandwich thesis' was for the COR to become the third chamber of the EU institutions ... but the European project turned out to be a club of states project. 
The language issue was more focused on by Catalans while the idea of a 'Europe of Regions' was popular. However, it has not been focused on in recent years. Interviewee 3 (2017) stated that:

Most spoken language in Catalonia is Castilian... The primary issue is not language, rather independence ... If there was a divide in the society between Catalan and Castilian speakers ... then independence would be impossible, the $\mathrm{CiU}$ always used Castilian ... Extra-parliamentary independence organizations emphasise that, in independent Catalonia, Catalan and Castilian would be co-official like now ... Castilian was widely used in the referendum campaign ... They emphasised that there would be dual citizenship to avoid the division of the society because otherwise there would not be majority in the referendum.

Some interviewees stated that, although some Catalans are disappointed with the EU, both Spaniards and Catalans generally remain pro-European. Interviewee 3 (2017) claimed that 'some Catalans are less Europhile now; they are disappointed by Europe'. Interviewee 6 (2017) emphasized that 'both for Catalans and Spaniards too, the EU means democratization, modernization; it still has a positive meaning'. Thus, despite the disappointment, the EU is still perceived mostly positively in Catalonia.

\section{Conclusion}

In 1978, a new Spanish Constitution was approved. The new political system was established to satisfy demands for regional autonomy, especially in those historical regions that had enjoyed some rights before, without disrupting the integrity of Spain. This is the main dilemma of the Spanish democracy: To balance the demands of the autonomous communities while preserving Spain's integrity.

After the introduction of the autonomy, the 'coffee for everyone' option did not satisfy Catalonia because it argued that a more asymmetrical arrangement would better reflect Spain's reality. The recentralisation efforts by Spain's central government triggered secessionist movements in Catalonia (Guibernau, 2000: 63).

Catalonia has used local, Spanish, Mediterranean and European arenas in the political field, and international presence have been emphasized more than the other regions. It has also emphasized cultural symbols, tried to use the EU to extend its autonomy. The CiU was very active in promoting the idea of 'Europe of Regions' (Keating, 1998: 163-164). However, this idea lost popularity after the 1990s.

Whereas only $20 \%$ of Catalans supported independence in $2010,49 \%$ did in 2013. In July 2017, a survey conducted by the Catalan government's Centre for Opinion Studies indicated that 35\% of Catalans support independence (Elcano 
Royal Institute, 2018: 11). Several domestic and external factors help explain rising support for independence in Catalonia. One of the domestic factors was the Constitutional Court's decision in 2010 while another one is the policies of the central (Rajoy) government. The most important external factor is economic crisis in Europe alongside the Scottish referendum.

Especially since the economic crisis, Catalan nationalism has abandoned its traditional cooperation with Spain's central government (Europenow Journal, 2018).

Catalonia has also been inspired by Scotland's referendum, although they have different contexts and legal frameworks. While Scotland is recognized as a constituent nation of the UK, Spain's constitution stresses the 'indivisibility and unity of the Spanish nation' (Calzada, 2017: 64).

Catalan society remains polarized. The pro-independence narrative portrays Spain as an obstacle for preserving Catalan cultural identity, political development and economic progress. This narrative implies that 'Catalan and Spanish became mutually exclusive' things (Europenow Journal, 2018).

Despite the EU's criticisms of Spain's central government because of using of violence by the police during the referendum day, the EU emphasized that, according to the Spanish constitution, this referendum is illegal and that the Catalan issue is Spain's internal affair. The EU's legal basis and its decisionmaking system support the maintenance of the sovereignty of its member states despite the challenges and attempts at independence by their regions.

Jose Ortega y Gasset stated in 1932 in the Spanish Parliament that 'the Catalan question cannot be solved, it can only be put up with' (cited in Europenow Journal, 2018). The Catalan issue was not solved after the independence referendum, which was illegal according to the Spanish Constitution. The EU emphasized this, with EU officials mostly declaring that it was Spain's internal affair. Meanwhile, the idea of 'Europe of Regions', which was popular and promoted by Catalonia in the 1990s, has faded away. Instead, there has been rise of populism, Euroscepticism and radical right parties in many states of Europe even including Spain recently. After the economic and migration crises, member states have maintained or even increased their power and influence within the EU framework. Thus, despite the challenges that the member states and the EU both face from the effects of globalization, the EU provides a supranational framework for its member states that helps them cope with the challenges both of globalization and sub-national regional demands.

For further research, a fieldwork may be conducted primarily in Barcelona after the referendum, also in Madrid and Brussels as well in order to analyze 
and compare the perceptions of Spain's central government and the policies and discourse of the EU political elites about the Catalan issue in more detail. In addition to these, a comparative analysis between the Catalan and Basque issues, changes in their relations with the central government, the reasons behind that and their relations with the EU may be compared. 


\section{References:}

Börzel, T. A. (2000) "From Competitive Regionalism to Cooperative Federalism: The Europeanization of the Spanish State of the Autonomies", Publius, 30 (2): 17-42.

Calzada, I. (2017) "Metropolitan and Post-national Urbanity Beyond (Pluri) nation (al)-states in the EU: Benchmarking Scotland, Catalonia and the Basque Country", Journal on Ethnopolitics and Minority Issues in Europe, 16: (1): 51-78.

Coates, C. (1998) "Spanish Regionalism and The European Union", Parliamentary Affairs, 51(2): 259-271.

Colomer, J. M. (2017) "The Venturous Bid for the Independence of Catalonia", Nationalities Papers, 45(5): 950-967.

Conversi, D. (2000) "From Centralist Dictatorship to Federal Democracy: the Case of Spain" in Günay G. Özdoğan and Gül Tokay (eds.), Redefining The Nation-State and Citizen, (İstanbul: Eren Pub.), pp: 151-175.

Conversi, D. (1990) "How Culture Can Influence Political Choices: Language Maintenance and Its Implications For The Catalan and Basque National Movements", $2^{\text {nd }}$ Conference of The International Society For The Study of European Ideas (ISSEI), Panel on Language and National Identity, Belgium.

Diaz Lopez Cesar, E. (1982) "The Autonomic State: A Democratic Challenge To The Creative Imagination" in Y. Mendy (ed.), Dix Ans De Regionalisation En Europe: Bilan Et Perspectives (1970-1980), (Paris: Editions Cujas), pp: 123-150.

Elcano Royal Institute (2018) "The Conflict in Catalonia", October 2017, $<\mathrm{http}$ ://www.realinstitutoelcano.org/wps/wcm/connect/c0f90dae-76d1-4a8e8f78-0058f048a44b/Catalonia-Dossier-Elcano-October-2017.pdf?MOD=

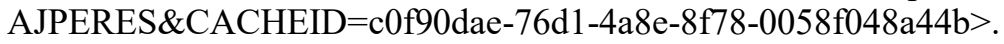

Elias, A. and Mees, L. (2017) "Between Accommodation and Secession: Explaining the Shifting Territorial Goals of Nationalist Parties in the Basque Country and Catalonia", Revistad'Estudis Autonomics i Federals, (25): 129165.

European Commission (2017) "Statement on the Events in Catalonia", 2 October, <https://ec.europa.eu/commission/presscorner/detail/en/STATE MENT_17_3626>.

EuropeNow Journal (2018) "The EU, Spain and the Catalan Question: An Affair Beyond the Spanish Border?", 31 January, <https://www.europenow journal.org/2018/01/31/8254/>. 
Gibbons, J. (1999) "Spain: A Semi-federal State?" in D. MacIver (ed.) The Politics of Multinational States, (London: Macmillan Pub.), pp: 271-291.

Guibernau, M. (2000) "Spain: Catalonia and the Basque Country", Parliamentary Affairs, 53(1), pp. 55-68.

Keating, M. and Hooghe, L. (1996) "By-passing The Nation-State? Regions and The EU Policy Process" in J. Richardson (ed.), European Union- Power and Policy Making, (London: Routledge Press), pp: 3-32.

Keating, M. (1998) The New Regionalism in Western Europe-Territorial Restructuring and Political Change, (Cheltenham: Edward Elgar Pub.).

Keating, M. (1988) State and Regional Nationalism-Territorial Politics and The European State, (New York: Harvester-Wheatsheaf Press).

Keating, M. (1995) "Europeanism and Regionalism" in B. Jones and M. Keating (eds.), The European Union and The Regions, (Oxford: Clarendon Press), pp: 1-22.

Keating, M. (1996) Nations Against The State- The New Politics of Nationalism in Quebec, Catalonia and Scotland, (London: Macmillan Press).

Lawson, B. "Catalonia: Implications of Potential Secession from Spain", $<$ http://estudioae.com/IHSCATALONIA.pdf $>$.

Molina, I. and Iglesias, Miguel O. (2015) "Catalonia Torn in Two", 2 October, $<$ https://www.politico.eu/article/catalonia-torn-in-two-spain-barcelonaindependence-scotland-referendum/ $>$.

Nagel Klaus, J. (2004) "Dilemmas of Stateless Nations in the EU" in R. Maiz and F. Requejo (eds.), Democracy, Nationalism and Multiculturalism, (London: Routledge Publishing), pp: 127-149.

Newhouse, J. (1997) “Europe's Rising Regionalism”, Foreign Affairs, 76(1): 67-84.

Teich, M. and Porter, R. (1993) The National Question in Europe in Historical Context, (New York: Cambridge University Press).

The New York Times (2017) "Crisis in Catalonia: The Independence Vote and Its Fallout", 26 June, <https://www.nytimes.com/2017/09/26/world/ europe/spain-catalonia-referendum.html $>$.

\section{The List of Expert Interviewees:}

Interviewee 1 (2017) Academic at IBEI (Institut Barcelona Estudis Internacionals), Barcelona, 26 June 2017.

Interviewee 2 (2017) Academic at IBEI, Barcelona, 26 June 2017. 
Interviewee 3 (2017) Academic at University of Pompeu Fabra, Barcelona, 28 June 2017.

Interviewee 4 (2017) Former member of Catalan Parliament, Barcelona, 29 June 2017.

Interviewee 5 (2017) Expert at a think tank, Barcelona, 28 June 2017.

Interviewee 6 (2017) Academic at University of Pompeu Fabra, Barcelona, 27 June 2017. 